\title{
KUALITAS SENSORIS DAGING ITIK AFKIR YANG DIBERI TEPUNG DAUN ASAM GELUGUR (GARCINIA ANTROVIRIDIS) DALAM RANSUM NONKONVENSIONAL TERFERMENTASI
}

\section{SENSORY QUALITY OF MEAT OF CULLED DUCKS FED FERMENTED NONCONVENTIONAL RATIONS WITH GARCINIA (GARCINIA ANTROVIRIDIS) LEAF MEAL INCLUSION}

\author{
Merliana $^{1}$, E Dihansih ${ }^{1 a}$, dan D Wahyuni ${ }^{1}$ \\ 1Programstudi Peternakan Fakultas Pertanian Universitas Djuanda Bogor, Jl. Tol Ciawi No. 1, Kotak \\ Pos 35 Ciawi, Bogor 16720. \\ aKorespondensi: Elis Dihansih, E-mail: elis.dihansih@unida.ac.id
}

(Received: 08-07-2020; Accepted: 11-10-2020)

\begin{abstract}
Duck meat is a nutritious food but it gains less interest from the people. This may be attributed to the fishy smell duck meat has. Garcinia contains organic acids including tartaric, citric, malic, and hydroxycitric acids. The main organic acid contained in garcinia is hydroxycitric acid (HCA) which has antilipidemic and antiobesity properties. This study was conducted at the poultry farm of Department of Animal Science, Djuanda University, Bogor for 40 days from May to June 2019. A completely randomized design with 4 treatment and 5 replicates was used. Treatments consisted of the inclusion of garcinia leaf meal in rations by $0 \%$ (R0, $2 \%$ (R1), 4\% (R2), and 6\% (R3). Data were subjected to a Kruskal Wallis test. Measurements were taken on hedonic and quality hedonic parameters including aroma, tenderness, color, taste, and juiciness. Results of the hedonic test showed that the inclusion of garcinia leaf meal in rations significantly $(\mathrm{P}<0.05)$ affected meat color. Significant differences $(\mathrm{P}<0.05)$ in meat color and taste were found based on the results of the quality hedonic test. The inclusion of garcinia leaf meal $6 \%$ in fermented nonconventional rations was found to increase panelist likeness in meat color and improve meat color brightness. No difference in aroma, tenderness, taste and juiciness in meat was found in all treatments.
\end{abstract}

Key words: culled duck, garcinia, organoleptic, fermented nonconventional ration, hydroxycitric acid

\begin{abstract}
ABSTRAK
Daging itik merupakan salah satu bahan pangan yang masih kurang diminati oleh masyarakat. Beberapa faktor yang menyebabkan kurangnya minat masyarakat untuk mengkonsumsi daging itik adalah karena adanya aroma bau amis. Asam gelugur (Garcinia antroviridis) mengandung asam-asam organik seperti asam tartarik, asam sitrat, asam malat dan asam hidroksisitrat. Asam hidroksisitrat (HCA) merupakan asam organik utama yang berkhasiat sebagai antilipidemik dan antiobesitas. Penelitian dilakukan selama 40 hari yaitu bulan Mei - Juni 2019 bertempat di kandang unggas Program Studi Peternakan Fakultas Pertanian Universitas Djuanda Bogor. Ransum yang digunakan adalah ransum nonkonvensional terfermentasi. Metode penelitian menggunakan Rancangan Acak Lengkap (RAL) dengan 4 perlakuan 5 ulangan. Setiap perlakuan terdiri dari R0 $=0 \%$ tepung daun asam gelugur, $\mathrm{R} 1=2 \%$ tepung daun asam gelugur, $\mathrm{R} 2=4 \%$ tepung daun asam gelugur, $\mathrm{R} 3=6 \%$ tepung daun asam gelugur. Data dianalisis menggunakan Kruskal Wallis. Peubah yang diamati yaitu uji hedonik dan uji mutu hedonik (aroma, keempukkan, warna, rasa dan juiceness). Hasil penelitian menunjukan bahwa pemberian tepung daun asam gelugur berbeda nyata $(\mathrm{P}<0,05)$ terhadap warna daging itik pada uji hedonik dan pada uji mutu hedonik berbeda nyata $(\mathrm{P}<0,05)$ terhadap warna dan rasa daging itik. Pemberian tepung daun asam gelugur (Garcinia antroviridis) sebesar $6 \%$ dalam ransum nonkonvensional terfermentasi meningkatkan kesukaan panelis terhadap warna daging dan meningkatkan kecerahan warna daging akan tetapi tidak merubah rasa, aroma, keempukan dan juiceness daging itik
\end{abstract}


Kata Kunci: Itik afkir, asam gelugur, organoleptik, ransum nonkonvensional terfermentasi, asam hidroksisitrat

Merliana, E Dihansih, D Wahyuni. 2020. Kualitas Sensoris Daging Itik Afkir Yang Diberi Tepung Daun Asam Gelugur (Garcinia Antroviridis) Dalam Ransum Nonkonvensional Terfermentasi. Jurnal Peternakan Nusantara 6(2): 47-56

\section{PENDAHULUAN}

Permintaan terhadap produk hasil ternak berupa daging terus mengalami peningkatan dari tahun ketahun. Akan tetapi sumber daya yang tersedia belum dikembangkan untuk bisa memenuhi kebutuhan protein hewani masyarakat. Salah satu ternak unggas yang mempunyai potensi untuk dikembangkan adalah ternak itik yaitu sebagai protein hewani penghasil daging dan telur yang dapat digunakan untuk memenuhi gizi masyarakat Indonesia. Menurut data Statistik Peternakan dan Kesehatan Hewan (2018) produksi daging itik meningkat pada tahun 2017 sebanyak 36.392 ton dan pada tahun 2018 sebanyak 38.004 ton.

Sumber protein hewani dari daging itik merupakan salah satu bahan pangan yang masih kurang diminati oleh masyarakat, banyak yang mengaagap bahwa daging itik berkualitas rendah, lain halnya dengan daging sapi, daging kambing maupun daging ayam. Faktor -faktor yang menyebabkan kurangnya minat masyarakat untuk mengkonsumsi daging itik adalah karena adanya aroma yang tidak sedap yaitu bau amis. Penyebab aroma bau amis yang terdapat dalam daging itik adalah karena adanya komponen volatile yang berasal dari hasil oksidasi lemak. Reaksi ini disebabkan oleh asam lemak tidak jenuh. Dalam daging itik kandungan asam lemak tidak jenuh lebih tinggi daripada daging ayam (Hustiany 2001).

Kualitas sensoris daging merupakan karakteristik daging yang dinilai dan dapat mempengaruhi penerimaan konsumen. Faktor yang menenukan kualitas daging meliputi warna, keempukan, aroma, rasa serta juicenesss. kualitas sensoris pada daging dapat dipengaruhi oleh faktor intrinsik dan ekstrinsik. Faktor intrinsik yang memepengaruhi kualitas daging antara lain spesies, umur, bangsa genetik, tipe, jenis dan pakan ternak. Faktor ekstrinsik yang berpengaruh terhadap kualitas daging antara lain meliputi metode pemasakan $\mathrm{pH}$ karkas dan daging, stimulasi listrik, pelayuan, bahan tambhan seperti enzim pengempuk daging, hormon, metode penyimpanan dan perservasi, antibiotik, marbling atau lemak intramuskuler macam otot daging dan lokasi pada suatu otot daging (Soeparno 2011)

Asam gelugur (Garcinia atroviridis) merupakan salah satu jenis tanaman dari genus Garcinia, jenis Garcinia atroviridis biasanya ditemukan di hutan tropis di bagian selatan dari Thailand dan Malaysia. Di Indonsia asam gelugur dapat ditemukan diwilayah bagian Sumatera Utara. Asam gelugur (Garcinia antroviridis) memiliki kandungan zat aktif berupa tanin, alkaloid, fenolik, saponin, protein dan karbohidrat selain itu asam gelugur juga mengandung asam-asam organik antara lain asam sitrat, asam tartarik dan asam malat. Asam hidroksisitrat (HCA) adalah asam oganik utama yang berperan untuk antiobesitas seta antilipidemik. HCA dalam buah garcinia terdapat sekitar 10-30\% (Meera et al 2013). Asam gelugur juga bersifat sebagai antioksidan dan mampu menurunkan berat badan (Chung 2006).

Berdasarkan asumsi diatas kendala yang dihadapi dalam pengembangan daging itik, yaitu bau amis karena kadar lemak yang tinggi. Oleh karena itu, dilakukan penelitian penggunaan tepung daun asam gelufgur (Garcinia antroviridis) yang ditmabahkan dalam pakan non konvensional terfermentasi sebagai penyusun ransum itik. Tujuan dari penelitian ini adalah untuk menguji kualitas sensoris daging itik yang diberi tepung daun asam gelugur (Garcinia antroviridis) dalam ransum non konvensional terfermentasi

\section{MATERI DAN METODE}

\section{Materi}

Penelitian dilaksanakan selama 40 hari mulai pada bulan Mei-Juni 2019, bertempat di kandang unggas Program Studi Peternakan Fakultas Pertanian dan uji sensoris dilakukan di Laboratorium Universitas Djuanda Bogor, Jln. Tol Ciawi No. 1 Bogor, Ternak yang digunakan 
dalam penelitian ini adalah itik lokal afkir yang didapatkan dari Cirebon sebanyak 40 ekor berjenis kelamin betina dan diberi perlakuan selama 40 hari. Bahan pakan yang digunakan pada penelitian ini sebagai ransum dasar yaitu jagung kuning, dedak halus, bungkil kedelai, tepung ikan, premix. DCP dan CaCO3. Pakan nonkonvensional yang digunakan yaitu bungkil kelapa dan bungkil inti sawit. Pakan tersebut difermentasi dengan menggunakan kapang Aspergillus niger. Pakan yang sudah difermentasi digunakan sebagai substitusi pakan dasar itik tegal dengan tambahan tepung daun asam gelugur. Berikut adalah susunan bahan pakan yang digunakan sebagai ransum itik lokal dapat dilihat pada Tabel 1.

Tabel 1 Susunan Bahan Pyang Digunakan Sebagai Ransum Itik Lokal.

\begin{tabular}{clc}
\hline No & \multicolumn{1}{c}{ Bahan pakan } & Jumlah $(\%)$ \\
\hline 1 & Jagung kuning & 40 \\
2 & Dedak halus & 19 \\
3 & Bungkil kedelai & 4,5 \\
4 & Tepung ikan & 4 \\
5 & Premix & 0,5 \\
6 & DCP & 1 \\
7 & $\mathrm{CaCO}_{3}$ & 1 \\
8 & Bungkil kelapa & 15 \\
9 & Bungkil inti sawit & 15 \\
\hline \multicolumn{2}{c}{ Total } \\
\hline
\end{tabular}

Tabel 2 Kandungan Nutrisi Ransum Setiap Perlakuan

\begin{tabular}{lllll}
\hline Perlakuan & R1 & R2 & R3 & R4 \\
\hline Air (\%) & 11.61 & 10,74 & 10,23 & 9,21 \\
Abu (\%) & 8,43 & 8,43 & 7,54 & 7,80 \\
Lemak (\%) & 13,32 & 2,57 & 3,74 & 3,34 \\
Protein (\%) & 4,25 & 13,32 & 13,18 & 12,00 \\
Serat Kasar & 4,25 & 4,25 & 8,97 & 9,30 \\
(\%) & & & & \\
BETN (\%) & 59,82 & 59,82 & 56,34 & 58,35 \\
Gross & 3814 & 4099 & 3918 & 4022 \\
Energi(Kal/gr) & & & & \\
\hline
\end{tabular}

Kandang yang digunakan pada penelitian ini adalah kandang battery yang berjumlah 40 unit dengan ukuran panjang $40 \mathrm{~cm}$, lebar $35 \mathrm{~cm}$ dan tinggi $35 \mathrm{~cm}$ yang terbuat dari kawat besi. Alat yang digunakan dalam penelitian ini adalah tempat pakan, tempat minum, kantong plastik, timbangan digital, kompor gas, oven, blender, panci besar, saringan nasi, ember.

\section{Perlakuan}

Perlakuan yang diberikan yaitu :

$\mathrm{R} 0=0 \%$ Tepung daun asam gelugur (kontrol)

$\mathrm{R} 1=$ Penambahan $2 \%$ tepung daun asam gelugur dalam ransum

$\mathrm{R} 2$ = Penambahan $4 \%$ tepung daun asam gelur dalam ransum

R3 = Penambahan 6\% tepung daun asam gelugur dalam ransum

\section{Rancangan Percobaan}

Rancangan yang digunakan pada penelitian ini menggunakan Rancangan Acak Lengkap

(RAL). Berikut adalah model matematika yang digunakan dalam penelitian (Hanafiah 2003):

Keterangan:

$$
Y_{i j}=\mu+T_{i}+\mathfrak{f}_{i j}
$$

$\mathrm{Y}_{\mathrm{ij}}=$ Nilai pengamatan dari perlakuan ke-i pada ulangan ke-j $(1,2,3)$.

$\mu=$ Nilai tengah umum.

$\mathrm{T}_{\mathrm{i}}=$ Pengaruh frekuensi pemberian tepung daun asam gelugur.

$£_{\mathrm{ij}}=$ Galat pada perlakuan ke-I dan ulangan ke $\mathrm{j}$

\section{Peubah yang Diamati}

Peubah yang diamati dalam penelitian ini adalah uji sensoris yang dibagi menjadi 2 yaitu, uji hedonik dan uji mutu hedonik. Parameter yang diuji meliputi, aroma, keempukkan, warna, rasa dan juiceness. Pada pengujian sampel diletakan didalam cup plastik yang diberi kode tiga digit anggka pada setiap perlakuan. Kemudian panelis diminta memberikan penilaian tingkat kesukaannya dengan kisaran 1 - 5 (1= sangat tidak suka, $2=$ tidak suka, $3=$ netral, 4= suka, 5= sangat suka) untuk uji hedonik. Pengujian uji mutu hedonik dengan 5 kategori peubah dan skor penilaian disajikan pada Tabel 3. 
Tabel 3 Skor Penilaian Uji Mutu Hedonik

\begin{tabular}{|c|c|c|}
\hline Peubah & Skor & Kriteria \\
\hline \multirow[t]{5}{*}{ Aroma } & 1 & $\begin{array}{l}\text { Sangat Beraroma } \\
\text { Amis }\end{array}$ \\
\hline & 2 & Beraroma Amis \\
\hline & 3 & $\begin{array}{l}\text { Cukup Beraroma } \\
\text { Amis }\end{array}$ \\
\hline & 4 & $\begin{array}{l}\text { Sedikit Beraroma } \\
\text { Amis }\end{array}$ \\
\hline & 5 & $\begin{array}{l}\text { Tidak Beraroma } \\
\text { Amis }\end{array}$ \\
\hline \multirow[t]{5}{*}{ Keempukkan } & 1 & Sangat Empuk \\
\hline & 2 & Empuk \\
\hline & 3 & Cukup Empuk \\
\hline & 4 & Sedikit Empuk \\
\hline & 5 & Tidak Empuk \\
\hline \multirow[t]{5}{*}{ Warna } & 1 & Sangat Gelap \\
\hline & 2 & Gelap \\
\hline & 3 & Cukup Cerah \\
\hline & 4 & Cerah \\
\hline & 5 & Sangat Cerah \\
\hline \multirow[t]{6}{*}{ Rasa } & 1 & Sangat Enak \\
\hline & 2 & Enak \\
\hline & 3 & Agak Enak \\
\hline & 4 & Tidak Enak \\
\hline & 5 & Sangat Tidak \\
\hline & & Enak \\
\hline \multirow[t]{5}{*}{ Juiceness } & 1 & Sangat Juiceness \\
\hline & 2 & Juiceness \\
\hline & 3 & Cukup Juiceness \\
\hline & 4 & Sedikit Juiceness \\
\hline & 5 & Tidak Juiceness \\
\hline
\end{tabular}

Sumber: Hafid et al (2000) yang telah

dimodifikasi sesuai kebutuhan peneliti.

\section{Prosedur Pelaksanaan}

Kandang yang digunakan dalam penelitian dibersihkan dan diberi sumber penerangan. Pearalatan untuk penelitian disiapkan seperti gelas ukur, tempat minum, timbangan, tempat pakan, ember dll.

\section{Persiapan Itik}

Itik yang diguanakan dalam penelitian adalah itik afkir sebanyak 40 ekor dengan keadaaan sehat, dan tidak cacat. Bobot badan awal itik ditimbang dan dicatat serta diberikan kode identitas perlakuan pada setiap kandang, penempatan kandang dan perlakuan dilakukan secara acak.

\section{Pembuatan Pakan Fermentasi}

Bahan pakan yang difermentasi menggunakan kapang Aspegiluss niger terdiri dari bungkil inti sawit dan bungkil kelapa. Bahan penyusun ransum terdiri dari jagung kuning, dedak halus, bungkil kedelai, tepung ikan, tepung ikan, premix, DCP, $\mathrm{CaCO}_{3}$. Berikut proses fermentasi pakan menurut Supriyati et al. (1998).

Tabel 4 Proses Fermentasi Pakan

\begin{tabular}{ll}
\hline No & \multicolumn{1}{c}{ Keterangan } \\
\hline 1 & $\begin{array}{l}\text { Bungkin kelapa / inti sawit disiapkan + } \\
\text { ditambahkan air (1 kg pakan : 600 ml } \\
\text { air) }\end{array}$ \\
\hline 2 & $\begin{array}{l}\text { Bungkin kelapa / inti sawit kemudian } \\
\text { diaduk dan dikukus selama 30 menit }\end{array}$ \\
\hline 3 & $\begin{array}{l}\text { Bungkin kelapa / inti sawit yang sudah } \\
\text { dikukus didinginkan sebelum dicampur }\end{array}$ \\
& dengan bahan fermentasi yaitu \\
& Aspergilus niger \\
\hline 4 & Bungkin kelapa / inti sawit \\
& dicampurkan inokulan fermentasi, \\
& inokulan yang digunakan antara lain \\
& (Urea 3,5g, CaCl 0,25g, KCL 0,75g, \\
& $\begin{array}{l}\text { MgSO4 2g, NaPO4 12,5 g), Aspergillus } \\
\text { niger }\end{array}$ \\
\hline 5 & Bungkin kelapa / inti sawit dan \\
inokulan dicampur rata dibungkus dan \\
siap untuk difermentasi secara anaerob \\
selama 3 hari. Bahan pakan yang telah \\
selesai difermentasi dikeringkan selama \\
3-4 hari dengan menggunakan sinar \\
matahari.
\end{tabular}

\section{Proses Pembuatan Tepung Daun Asam gelugur}

Daun asam yang digunakan adalah daun asam gelugur ( Garcinia antroviridis). Berikut adalah proses pembuatan pembuatan daun asam. 


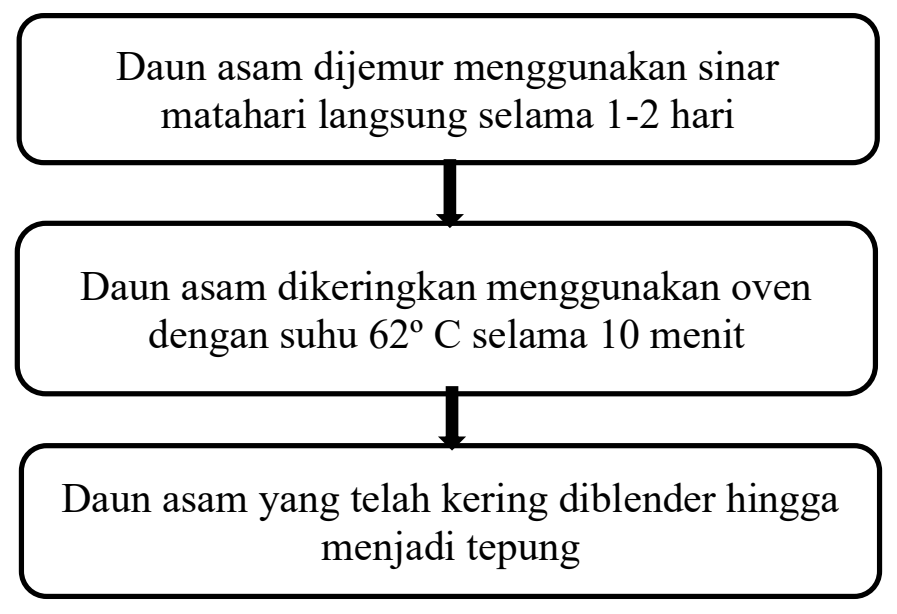

Gambar 1Proses pembuatan tepung daun asam

Pemberian pakan dilakukan 2 kali sehari yaitu pada pukul 08.00 dan pukul 16.00 WIB. Pemberian tepung daunasam gelugur pada ternak diberikan pada saat pemberian pakan dengan mencampurkan kedalam pakan nonkonvensional terfermentasi. Rangkaian kegiatan lain adalah pembersihan kandang, pengisian air minum dan pengambilan feses.

Pemotongan itik dilakukan setelah perlakuan pada itik selesai atau 40 hari. Metode pemotongan dilakukan sesuai dengan syariat Islam, dengan memutuskan arteri karotis, esophagus dan vena jugularis yang berada antara kepala dan leher. Kemudian itik yang sudah dipotong digantung agar darah bisa mengalir, selanjutnya itik dimasukkan ke dalam air yang telah dipanaskan untuk memudahkan pencabutan bulu, setelah itu dilakukan pengkarkasan untuk mendapatkan karkas yang diambil untuk pengambilan data adalah bagian paha.

Pengambilan sampel untuk uji organoleptik menggunakan daging dan kulit paha itik. Masing-masing sampel sesuai perlakuan direbus dengan waktu 5 menit menggunakan presto. Daging dipotong dengan bentuk dadu kecil, disajikan didalam cup plastik yang diberi kode dengan angka sebanyak 3 digit pada setiap cup sampel.

Panelis untuk uji hedonik dan uji mutu hedonik adalah panelis tidak terlatih sebanyak 30 orang. Sebelum pengujian dimulai panelis diberi pengarahan terlebih dahulu oleh peneliti mengenai cara pengisian uji hedonik maupun uji mutu hedonik. Panelis akan menilai sampel daging yang diletakkan pada cup plastik dengan kode yang telah ditentukan peneliti. Pengujian sensoris ini dilaksanakan di Laboratorium Universitas Djuanda Bogor.

\section{HASIL DAN PEMBAHASAN}

\section{Uji Hedonik}

Uji Organoleptik atau biasa juga disebut dengan uji sensoris merupakan suatu cara untuk mengukur, menguji atau mengamati aroma, keempukkan, warna, rasa dan juiceness. dari suatu produk dengan menggunakan kepekaan alat indera manusia. Penilaian dalam uji sensoris meliputi uji hedonik dan ujimutu hedonik. Uji hedonik merupakan penilaian yang dilakukan untuk mengemukakan tanggapan kesukaaan atau ketidaksukaan panelis terhadap sampel dengan skala 1-5 (1= sangat tidak suka, $2=$ tidak suka, $3=$ netral, $4=$ suka, $5=$ sangat suka). Uji Kruskal Wallis digunakan dalam pengolahan data untuk mengetahui tingkat penerimaan maupun penolakan terhadap sampel. Nilai rataan dalam uji hedonik daging itik dapat dilihat pada Tabel 5.

Tabel 5 rataan Ui hedonic

\begin{tabular}{ccccc}
\hline \multirow{2}{*}{ Peubah } & \multicolumn{4}{c}{ Perlakuan } \\
\cline { 2 - 5 } & $\mathrm{R} 0$ & $\mathrm{R} 1$ & $\mathrm{R} 2$ & $\mathrm{R} 3$ \\
\hline Aroma & $3,23 \pm 0,94$ & $3,4 \pm 0,77$ & $3,33 \pm 0,72$ & $3 \pm 0,00$ \\
Keempukkan & $3,28 \pm 0,80$ & $3,23 \pm 0,93$ & $2,97 \pm 0,85$ & $3,33 \pm 1,03$ \\
& $3,13 \pm 0,70$ & & & \\
Warna & $\mathrm{a}$ & $3,23 \pm 0,77^{\mathrm{a}}$ & $3,33 \pm 0,88^{\mathrm{ab}}$ & $3,63 \pm 0,67^{\mathrm{b}}$ \\
Rasa & $3,18 \pm 0,85$ & $3,13 \pm 0,93$ & $3,2 \pm 0,96$ & $3,4 \pm 0,91$ \\
Juiceness & $3,17 \pm 0,78$ & $3,2 \pm 0,80$ & $3,2 \pm 0,81$ & $3,3 \pm 0,97$ \\
\hline
\end{tabular}

Keterangan: Hurup superskrip yang berbeda pada baris yang sama menunjukan perbedaan yang nyata $(\mathrm{P}<0,05)$. R0: Pakan non konvensional terfermentasi $+0 \%$ Tepung daun asam gelugur, R1: Pakan non konvensional terfermentasi $+2 \%$ Tepung daun asam gelugur. R2: Pakan non konvensional terfermentasi $+4 \%$ Tepung daun asam gelugur, R3: Pakan non konvensional terfermentasi $+6 \%$ Tepung daun asam gelugur.

Berdasarkan hasil analisis Kruskal Wallis dari setiap perlakuan menunjukan bahwa pemberian tepung daun asam gelugur pada pakan non konvensional terfermentasi berpengaruh nyata $(\mathrm{P}<0,05)$ terhadap warna tetapi tidak berpengaruh nyata $(\mathrm{P}>0,05)$ terhadap aroma, keempukkan, rasa dan juiceness daging itik.

Penilaian panelis pada uji hedonik terhadap seluruh peubah pada daging itik dapat diketahui pada tabel 5 yang diuji meliputi, aroma, keempukkan, warna, rasa dan juiceness. Hasil analisis terhadap warna daging itik dapat diketahui pada tabel 5 yang memberikan hasil bahwa peubah pada warna berbeda nyata $(\mathrm{P}>0,05)$, nilai rataan paling tinggi berada pada perlakuan R3 yaitu dengan penambahan $6 \%$ tepung daun asam gelugur dalam ransum dengan nilai rataan 3,63, menunjukan bahwa 
panelis lebih suka warna daging itik pada perlakuan ini (R3), dibandingkan dengan perlakuan R0 ( $0 \%$ tepung daun asam gelugur), $\mathrm{R} 1$ (2\% tepung daun asam gelugur) dan R2 (4\% tepung daun asam gelugur) yang menunjukan tingkat kesukaan panelis terhadap sampel daging itik netral dengan kisaran nilai rataan 3. Hal ini dibuktikan pada diagram uji hedonik gambar 3 warna pada perlakuan R3 memiliki posisi yang lebih tinggi dibandingkan dengan perlakuan lainnya yang berarti semakin tinggi semakin disukai panelis. Tetapi nilai rataan pada tabel 5 menunjukan semakin meningkatnya tepung daun asam gelugur yang ditambahkan dalam ransum, meningkat pula nilai rataan kesukaan panelis terhadap daging itik. Hasil ini menunjukan bahwa semakin tinggi penambahan tepung daun asam gelugur dalam ransum non konvensional terfermentasi maka akan meningkatkan kesukaan panelis terhadap warna daging itik. Hasil penelitian Dihansih et al (2017) yang menggunakan pakan dengan tambahan larutan daun sirih dengan level 2,5\% yang menunjukan hasil uji sensoris berbeda nyata $(\mathrm{P}<0,05)$ terhadap warna daging itik dengan nilai rataan sebesar 1,76 yang menunjukan bahwa panelis lebih suka - sangat suka pada daging itik. Faktor utama yang dapat mempengaruhi penentu warna utama daging adalah konsentrasi pigmen daging (mioglobin) (Soeparno 2005).

Berdasarkan hasil analisis Kruskal Wallis bahwa pemberian tepung daun asam gelugur pada setiap perlakuan pada peubah aroma daging itik menunjukan hasil yang tidak berbeda nyata $(\mathrm{P}>0,05)$. Rataan penilaian panelis terhadap uji hedonik dari seluruh perlakuan pada aroma daging itik dengan nilai rataan sebesar 3,24 yang berarti bahwa tingkat kesukaan panelis terhadap aroma daging itik berada pada kisaran netral. Hasil penelitian Fernando (2007) yaitu pemberian tepung daun sambiloto dalam pakan, skor uji organoleptik pada daging berkisar dari 2,72-3,08 dan berkisar pada daerah netral yang berarti panelis menerima aroma sampel.

Berdasarkan hasil analisis Kruskal Wallis bahwa pemberian tepung daun asam gelugur pada tingkat keempukkan daging itik menunjukan pengaruh yang tidak berbeda nyata $(\mathrm{P}<0,05)$. Penilaian kesukaan panelis terhadap uji hedonik pada peubah keempukkan daging itik dari seluruh nilai rataan perlakuan yaitu sebesar 3,20 menunjukan bahwa tingkat kesukaan panelis terhadap daging itik berada pada kisaran netral. Berbeda dengan hasil penelitian Dihansih et al (2017) yang menggunakan pakan dengan tambahan larutan daun sirih, penilaian kesukaan panelis terhadap keempukkan berada pada nilai rataan sebesar 2,47 untuk seluruh perlakuan, yang berarti tingkat kesukaan panelis berada pada daerah suka. Keempukkan pada daging sangat mennetukan kualitas daging dan mempengaruhi daya terima konsumen Mattaputty dan Suryana (2010).

Berdasarkan hasil analisis Kruskal Wallis bahwa pemberian tepung daun asam gelugur dari seluruh perlakuan pada peubah rasa daging itik menunjukan pengaruh yang tidak berbeda nyata $(\mathrm{P}>0,05)$. Penilaian panelis terhadap uji hedonik pada rasa daging itik dengan nilai seluruh rataan 3,24 menunjukan bahwa tingkat kesukaan panelis terhadap rasa daging itik netral. Berbeda dengan hasil penelitian Dihansih et al (2017) kualitas daging itik yang diberikan penambahan larutan daun sirih sebanyak $2,5 \%$ yang berpengaruh nyata $(\mathrm{P}<0,05)$ terhadap daging itik dengan rataan 2,06 panelis menilai suka terhadap sampel daging itik. Penelitian Siti et al (2016) kualitas daging uggas yang diberikan tambahan tambahan ekstrak daun papaya terfementasi tidak berpengaruh nyata $(\mathrm{P}<0,05)$ terhadap rasa dengan nilai rataan 3,28 yang menunjukan panelis menilai tidak suka.

Berdasarkan hasil analisis Kruskal Wallis bahwa pemberian tepung daun asam gelugur pada peubah juiceness daging itik menunjukan pengaruh yang tidak berbeda nyata $(\mathrm{P}>0,05)$. Penilaian panelis terhadap uji hedonik pada juiceness daging itik dengan nilai rataan 3,22 menunjukan bahwa tingkat kesukaan panelis terhadap juiceness daging itik netral. Soeparno (2005) mengatakan bahwa juiceness dalam daging yang dimasak mempunyai 2 komponen organoleptik yaitu, impresi kebasahan selama awal pengunyahan oleh pembasahan cairan daging secara cepat. Daging yang berkualitas baik akan terasa lebih juicy. Perbedaan tersebut disebabkan oleh tingginya kadar lemak 
intramuscular pada daging yang berkualitas baik.

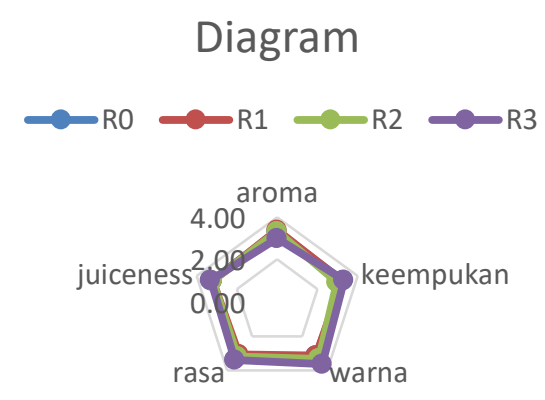

Gambar 2 Diagram Hasil Uji Hedonik

\section{Uji Mutu Hedonik}

Uji mutu hedonik meliputi aroma, keempukkan, warna, rasa dan juiceness dengan kisaran penilaian $1-5$ yang lebih spesifik. Penilaian mutu hedonik diberikan panelis sesuai dengan alat indera manusia meliputi mata (penglihatan), hidung (penciuman), dan lidah (pengecap rasa). Hasil rataan uji mutu hedonik pada setiap perlakuan disajikan pada Tabel 6 .

Tabel 1 Rataan Nilai Uji Mutu Hedonik Daging Itik

\begin{tabular}{|c|c|c|c|c|}
\hline \multirow{2}{*}{ Peubah } & \multicolumn{4}{|c|}{ Perlakuan } \\
\hline & R0 & R1 & $\mathrm{R} 2$ & R3 \\
\hline Aroma & $\begin{array}{l}2,70 \pm 1,2 \\
4\end{array}$ & $\begin{array}{l}2,33 \pm 1,1 \\
2\end{array}$ & $2,80 \pm 1,03$ & $\begin{array}{l}2,83 \pm 1,0 \\
9\end{array}$ \\
\hline $\begin{array}{l}\text { Keempuk } \\
\text { an }\end{array}$ & $\begin{array}{l}2,60 \pm 1,0 \\
0\end{array}$ & $\begin{array}{l}2,77 \pm 1,0 \\
7\end{array}$ & $2,73 \pm 1,23$ & $\begin{array}{l}2,80 \pm 1,3 \\
2\end{array}$ \\
\hline Warna & $\begin{array}{l}2,00 \pm 1,2 \\
3^{\mathrm{a}}\end{array}$ & $\begin{array}{l}1,87 \pm 1,2 \\
5^{\mathrm{a}}\end{array}$ & $\begin{array}{l}1,70 \pm 1,24 \\
\text { a }\end{array}$ & $\begin{array}{l}2,73 \pm 1,6 \\
0^{\mathrm{b}}\end{array}$ \\
\hline Rasa & $\begin{array}{l}3,30 \pm 0,8 \\
4^{b}\end{array}$ & $\begin{array}{l}2,77 \pm 0,9 \\
0^{\mathrm{a}}\end{array}$ & $\underset{\mathrm{ab}}{2,97 \pm 0,96}$ & $\begin{array}{l}3,43 \pm 0,9 \\
4^{b}\end{array}$ \\
\hline $\begin{array}{l}\text { Juicen } \\
\text { ess }\end{array}$ & $\begin{array}{l}2,70 \pm 1,0 \\
2\end{array}$ & $\begin{array}{l}2,97 \pm 1,0 \\
0\end{array}$ & $2,67 \pm 0,92$ & $\begin{array}{l}2,77 \pm 1,1 \\
7\end{array}$ \\
\hline
\end{tabular}

Keterangan: Hurup superskrip yang berbeda pada baris yang sama menunjukan perbedaan yang nyata $(\mathrm{P}<0,05)$. R0: Pakan non konvensional terfermentasi $+0 \%$ Tepung daun asam gelugur, R1: Pakan non konvensional terfermentasi $+2 \%$ Tepung daun asam gelugur. R2: Pakan non konvensional terfermentasi $+4 \%$ Tepung daun asam gelugur, R3: Pakan non konvensional terfermentasi $+6 \%$ Tepung daun asam gelugur.
Penilaian panelis terhadap aroma daging itik pada uji mutu hedonik menghasilkan nilai rataan seluruh perlakuan sebesar 2,67 yang berarti menunjukan bahwa tingkat penilaian panelis terhadap aroma daging itik yang diberi tepung daun asam gelugur berada pada kisaran cukup beraroma amis. Berdasarkan analisis Kruskal Wallis pemberian tepung daun asam gelugur pada seluruh perlakuan terhadap aroma daging itik menunjukan hasil yang tidak berbeda nyata $(\mathrm{P}>0,05)$. Hasil penelitian Djawang et al (2019) yang melakukan penelitian penambahan nanokapsul jus kunyit yang ditambahkan pada pakan itik melaporkan bahwa pada aroma daging itik tidak berbeda nyata $(\mathrm{P}>0,05)$. Nilai rataan panelis terhadap aroma daging itik sebesar 3,2 artinya berada dalam kisaran agak sedikit amis. Berbeda dengan hasil penelitian Febriana (2006) daging itik dengan penambahan tepung daun beluntas sebanyak 2\% memiliki tingkat bau amis terendah yang menunjukan berbeda nyata dari perlakuan lainnya. Aroma atau bau daging dihasilkan dari substansi-substansi volatile yang ditangkap oleh reseptor penciuman yang ada dibelakang hidung yang selanjutnya diinterprestasikan oleh otak (Warris 2000). Menurut Soeparno (2005) aroma daging olahan juga dapat dipengaruhi oleh umur ternak, tipe pakan, jenis kelamin, lemak, bangsa, kondisi pemotongan daging setelah pemotongan, lama penyimpanan daging serta lama, jenis dan temperatur pemasakan.

Berdasarkan hasil analisis Kruskal Wallis pemberian tepung daun asam gelugur dalam ransum terhadap keempukkan daging itik memberikan hasil yang tidak berbeda nyata $(\mathrm{P}>0,05)$. Pada tabel 6 dapat diketahui bahwa pada seiap perlakuan penilaian panelis terhadap keempukkan daging itik menghasilkan nilai rataan 2,73 yang menunjukan bahwa keempukkan daging berada dalam kisaran cukup empuk. Berbeda dengan hasil penelitian Djawang et al (2019) yang menambahkan nanokapsul jus kunyit pada pakan menghasilkan rataan nilai dari panelis dengan rataan 2,16 yaitu dengan kisaran daging empuk.

Menurut Suradi (2006) kapasitas mengikat air merupakan faktor mutu yang penting karena berpengaruh langsung terhadap keadaan 
fisik daging seperti keempukkan. Faktor lain yang dapat mempengaruhi keempukan pada daging adalah komposisi daging itu sendiri yaitu berupa tenunan pengikat, serabut daging, sel-sel lemak yang ada diantara serabut daging (Reny 2009).

Berdasarkan hasil analisis Kruskal Wallis pada warna daging itik memberikan hasil yang berbeda nyata $(\mathrm{P}<0,05)$. Pada tabel 6 penilaian panelis terhadap R0, R1 dan R2 menunjukan nilai rataan paling rendah yaitu $1,70-2,00$ yang berarti berada dalam kisaran gelap sedangan penilaian panelis terhadap R3 memiliki nilai yang lebih tinggi yaitu 2,73 yang berarti warna daging itik berada dalam kisaran cukup cerah. Hal ini diakibatkan oleh penurunan $\mathrm{pH}$ daging yang disebabkan oleh asam yang terkandung dalam asam gelugur yaitu asam sitrat. Konsentrasi asam sitrat yang lebih besar dan lebih banyak mengandung senyawa asam yang mampu menghambat terbentuknya pewarnaan pada daging. Hasil penelitian Dihansih et al (2017) yang memberikan larutan daun sirih pada pakan penilaian dari panelis terhadap warna pada uji mutu hedonik memiliki rataan pada seluruh perlakuan 2,00 yang menunjukan bahwa warna pada sampel daging adalah merah cerah. Menurut Soeparno (2005) faktor - faktor yang mempengaruhi warna daging adalah pakan, spesies, bangsa, umur, jenis kelamin, stress, tingkat aktivitas, tipe otot, $\mathrm{pH}$ dan oksigen. Faktor- faktor ini dapat mempengaruhi konsentrasi pigmen daging myoglobin, tipe molekul myoglobin, status kimia myoglobin dan kondisi kimia serta fisik komponen lain dalam daging mempunyai peranan besar dalam menentukan warna daging. Zulfahmi (2013) menyatakan bahwa warna merupakan kesan yang dihasilkan oleh indra mata terhadap cahaya yang dipantulkan oleh benda tersebut.

Berdasarkan analisis uji Kruskal Wallis nilai pada rasa daging itik memberikan hasil yang berbeda nyata $(\mathrm{P}<0,05)$. Dapat diketahui pada tabel 6 bahwa penilaian panelis terhadap rasa daging itik pada uji mutu hedonik dari setiap perlakuan menunjukan bahwa pada setiap perlakuan tidak merubah rasa daging itik, nilai rataan penilaian panelis dari seluruh perlakuan sebesar 3,12 yang menunjukan bahwa penilaian panelis terhadap rasa daging itik dalam kisaran agak enak. Hasil penelitian Dihansih et al (2017) bahwa penambahan larutan daun sirih 7,5\% dalam pakan itik menunjukan bahwa panelis menilai enak pada rasa daging itik.

Rataan dari seluruh perlakuan pada peubah juiceness uji mutu hedonik daging itik pada tabel 6 yaitu sebesar 2,78 hal ini menunjukan daging itik berada dalam kisaran cukup juiceness. Juiceness pada daging yang telah dimasak mempunyai komponen kandungan air selama awal pengunyahan yang disebabkan stimulan lemak terhadap salivasi (Soeparno 2005). Juiceness pada daging dipengaruhi oleh adanya lemak intramuscular marbling sebagai stimulan terhadap salivasi dengan adanya kesan cairan yang dilepaskan selama pengunyahan dan salivasi yang diproduksi (Khaerina et al 2017).

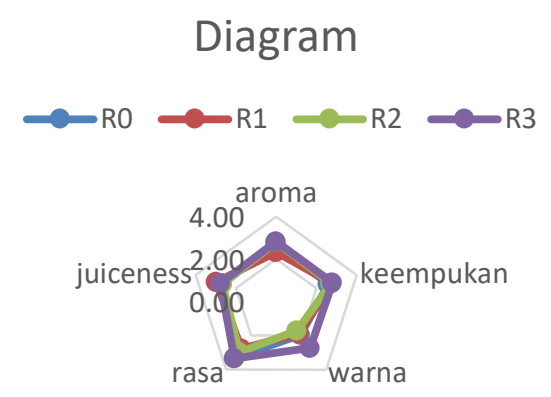

Gambar 1 Diagram Hasil Uji Mutu Hedonik

KESIMPULAN DAN IMPLIKASI

\section{Kesimpulan}

Pemberian tepung daun asam gelugur (Garcinia antroviridis) sebesar 6\% dalam ransum nonkonvensional terfermentasi meningkatkan kesukaan panelis terhadap warna daging dan meningkatkan kecerahan warna daging akan tetapi tidak merubah rasa, aroma, keempukan dan juiceness daging itik.

\section{Implikasi}

Penelitian lebih lanjut sebaiknya menambahkan $6 \%$ tepung daun asam gelugur dalam ransum nonkonvensional. 


\section{DAFTAR PUSTAKA}

[Ditjen PKH] Direktorat Jendral Peternakan dan Kesehatan Hewan. Statistik Peternakan dan Kesehetan Hewan 2018. Direktorat Jendral Peternakan. Departemen Pertanian RI.

Chung CS. 2006. Sweet and Sour, the Lovely Gelugor. Gardenwise Vol. 2(6): 18-19.

Dihansih E, Handarini R, Haerina $N$. 2017.Kualitas Sensoris Daging Itik Lokal Jantan (Anas Platyhrinchos) yang Diberi Larutan Daun Sirih (Pipper Betle Linn) dalam Pakan Komersil. Jurnal Peternakan Nusantara ISSN 2442-2541 VOL 3 No 1.

Djawang VUP, Sundari A, Susiati M. 2019. Pengaruh Pemberian Nanokapsul Jus Kunyit dalam Ransum Terhadap Kualitas Karkas dan Organoleptik Daging Itik Lokal Jantan. [Skripsi]. Fakultas Agroindustri. Universitas Mercu Buana.

Febriana D. 2006. Sifat Organoleptik Daging dan Sosis dari Itik yang mendapat Tepung Daun Beluntas (Pluchea indica L.) dalam Pakan. [Skripsi]. Fakultas Peternakan. Institut Pertanian Bogor. Bogor.

Fernando D. 2007. Sifat Fisik dan Organoleptik Daging Ayam Broiler yang diberi Pakan dengan Penambahan Tepung Daun Sambiloto. [Skripsi]. Fakultas Peternakan. Institut Pertanian Bogor. Bogor.

Hafid H, Nuraini, Syam A. 2000. Kualitas Daging Kambing Lokal dengan Metode Pelayuan dan Pemasakan serta Umur yang Berbeda. Laporan Penelitian. Fakultas Pertanian. Universitas Haluoleo. Kendari.

Hustlany R. 2001. Identifikasi dan Karakterisasi Komponen Off-odor pada Daging Itik [Skripsi]. [Bogor (Indonesia)] IPB.

Khaerina N, Dihansih E, Handarini R. 2017. Kualitas Sensoris Daging Itik Lokal Jantan (Anas Platyhrinchos) yang Diberi Larutan Daun Sirih (Pipper Betle Linn) dalam Pakan Komersil. Jurnal Peternakan Nusantara ISSN 2442-2541 VOL 3 No 1.
Matitaputty PR, Suryana. 2010. Karakteristik Daging Itik dan Permasalahan Serta Upaya Pencegahan Off-flavoer Akibat Oksidasi Lipida. Wartazoa 3 (20): 130-138.

Meera A, Prakash SJ, Prakash SO. 2013. Garcinia Indica for Metabolic Syndrome-a Review. Internastional Jornal of Experimental Pharmacologi. Vol 3, Issue 2;57-60.

Reny DT. 2009. Keempukan Daging dan Faktorfaktor yang Mempengaruhinya. Balai Teknologi Pertanian, Lampung.

Siti NW, Sukmawati IN, Ardika IN, Sumerta NM, Witariadi NN, Kusumawati C, Roni GK. 2016. Pemanfaatan Ekstrak Daun Pepaya Terfermentasi untuk Meningkatkan Kualitas Daging Ayam Kampung. Majalah Ilmiah Peternakan Vol 19 (2).

Soeparno. 2005. Ilmu dan Teknologi Daging. Gadjah Mada University Press. Yogyakarta.

Soeparno. 2009. Ilmu dan Teknologi Daging. Cetakan kelima. Gadjah Mada University Press, Yogyakarta.

Soeparno. 2011. Ilmu Nutrisi dan Gizi Daging. Cetakan pertama. Gadjah Mada University Press, Yogyakarta

Suprijatna E. 2010. Strategi Pengembangan Ayam Lokal Berbasis Sumber Daya Lokal dan Berwawasan Lingkungan. Prosiding Seminar Nasional Unggas Lokal ke IV. Hal. 55 - 79.

Warris. 2000. Meat Science an Introductory Text. CABI Publishing, Bristol.

Winarno FG. 1997. Keamanan Pangan [naskah akademis]. Institut Pertanian Bogor, Bogor.

Winarno FG. 2002. Kimia Pangan dan Gizi. Gramedia Pustaka Utama, Jakarta.

Zulfahmi M, Pramono YB, Antonius H. 2013. Pengaruh Marinasi Ekstrak Kulit Nenas (Ananas Comocus L. Merr) Pada Daging Itik Tegal Betina Afkir Terhadap Kualitas Keempukkan dan Organoleptik. Jurnal Pangan dan Gizi. Vol. 4 No. 8. 
